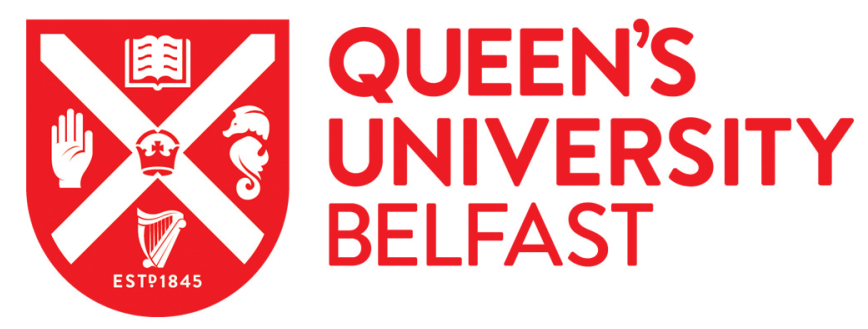

\title{
First Radiocarbon Chronology for the Early Iron Age Sites of Central Kazakhstan (Tasmola Culture and Korgantas Period)
}

Beisenov, A. Z., Svyatko, S. V., Kasenalin, Al. E., Zhambulatov, K. A., Duisenbai, D., \& Reimer, P. J. (2016). First Radiocarbon Chronology for the Early Iron Age Sites of Central Kazakhstan (Tasmola Culture and Korgantas Period). Radiocarbon, 58(1), 179-191. https://doi.org/10.1017/RDC.2015.18

\section{Published in:}

Radiocarbon

\section{Document Version:}

Peer reviewed version

Queen's University Belfast - Research Portal:

Link to publication record in Queen's University Belfast Research Portal

\section{Publisher rights}

(c) 2016 by the Arizona Board of Regents on behalf of the University of Arizona.

This work is made available online in accordance with the publisher's policies. Please refer to any applicable terms of use of the publisher.

\section{General rights}

Copyright for the publications made accessible via the Queen's University Belfast Research Portal is retained by the author(s) and / or other copyright owners and it is a condition of accessing these publications that users recognise and abide by the legal requirements associated with these rights.

\section{Take down policy}

The Research Portal is Queen's institutional repository that provides access to Queen's research output. Every effort has been made to ensure that content in the Research Portal does not infringe any person's rights, or applicable UK laws. If you discover content in the Research Portal that you believe breaches copyright or violates any law, please contact openaccess@qub.ac.uk. 
Title: First Radiocarbon Chronology for the Early Iron Age Sites of Central Kazakhstan (Tasmola Culture and Korgantas Period)

Authors: Arman Z. Beisenov ${ }^{1}$, Svetlana V. Svyatko ${ }^{2, *}$, Aibar E. Kasenalin ${ }^{1}$, Kairat A. Jambulatov ${ }^{1}$, Daniyar Duisenbai ${ }^{1}$, Paula J. Reimer ${ }^{2}$

1) Institute of Archaeology n.a. A. Kh. Margulan, 44 Avenue Dostyk, st. Shevchenko 28, Almaty 050010, Kazakhstan

2) ${ }^{14} \mathrm{CHRONO}$ Centre for Climate, the Environment, and Chronology, Queen's University of Belfast, Belfast BT7 1NN, Northern Ireland, UK

* Corresponding Author:

Tel.: +44 (0)2890973974

E-mail: s.svyatko@qub.ac.uk

Abstract: We present the first radiocarbon dates of Early Iron Age sites of Central Kazakhstan (in total, 24 dates for 16 recently excavated sites). Archaeologically, the sites have been attributed to the Tasmola Culture of the Saka period and later Korgantas phase of the early Hun period. The new AMS ${ }^{14} \mathrm{C}$ dates suggest that the majority of analysed Tasmola sites belong to the beginning of the $8^{\text {th }}-5^{\text {th }}$ c. cal BC, while Korgantas dates to the $4^{\text {th }}-2^{\text {nd }} \mathrm{c}$. cal BC. This corresponds with the latest archaeological data for the region however it is somewhat contrary to the traditional perception of the chronology of Scythian period in Central Kazakhstan. The new dates suggest the beginning of the Early Scythian period in the region in at least the late $9^{\text {th }}$ or $8^{\text {th }}$ c. $\mathrm{BC}$ rather than $7^{\text {th }} \mathrm{c}$. $\mathrm{BC}$ according to the traditional approach.

Keywords: Tasmola Culture, Korgantas period, Saka, Hun, Central Kazakhstan, Early Iron Age 


\section{Introduction}

The use of radiocarbon dating is a crucial and inherent aspect of modern day archaeological research. A growing body of ${ }^{14} \mathrm{C}$ dates is being released for a number of Eurasian Steppe regions, including Southern Siberia (Alekseev et al. 2001; Svyatko et al. 2009; Kiryushin and Tishkin 2009), Baraba foreststeppe (Molodin et al. 2012), southern Ural Mountains (Hanks et al. 2007), North Caucasus (Hollund et al. 2010; Higham et al. 2010), North Caspian steppes (Shishlina et al. 2009, 2012, 2014), Dnieper basin (Alekseev et al. 2001; Lillie 1998; Lillie et al. 2009), and the steppes in general (Chernykh et al. 2004). However, in the very heart of the Eurasian Steppe region - Kazakhstan - archaeological research using radiocarbon dating is only in its formative stage. A number of ${ }^{14} \mathrm{C}$ dates have been obtained for the Kazakhstan sites since the 1980s, however, these mostly represented isolated attempts to investigate single burials, sites etc., and in most cases remained unpublished. Such a sporadic approach could not address multiple and diverse chronological issues of either particular sites or entire historical periods. Partly, the insufficiency of radiocarbon research was compensated with sophisticated and well elaborated comparative-typological (i.e. "archaeological") dating, developed by a number of research groups.

As a result, no systematic radiocarbon databases have been created for the archaeological cultures of Kazakhstan. This research will present the first radiocarbon chronology for the region, specifically for the Early Iron Age sites of the Central Kazakhstan.

\section{Archaeological Background}

\section{Cultural geography of Central Asia in the Early Iron Age}

The development of the Early Iron Age archaeological cultures of Kazakhstan was determined by the geographical specifics of this land located at the border of Asia and Europe and its position as a unique gateway between the two continents. To the south, the land bordered with the ancient civilizations of Iran, Chorasmia and Bactria. Despite the long history of scientific investigations of the region, initiated by V. Radlov more that century and a half ago (Sorokin 1969), by the first half of the $20^{\text {th }} \mathrm{c}$. the area was regarded generally as hardly ever populated, deserted land lost between European and Asian Scythia. To date, this perception has changed dramatically, as a number of impressive Saka, Savromatian and Sarmatian archaeological complexes have been found. Step by step, the role of ancient Kazakhstan among the Early Iron Age cultures of the Eurasian steppe is being recognized.

Central Kazakhstan is one of the key regions of ethno-cultural processes in the Early Iron Age Eurasian Steppe. Abundant in rich sources of copper, the area became a hearth of powerful Bronze Age cultures of the Eurasian Steppe, whose achievements formed a basis for the later cultures of the Early Iron Age. Prehistoric populations of Central Kazakhstan played a bridging role in the exchange of a variety of achievements and innovations between the southern sedentary civilizations (such as Chorasmian and Bactrian) and the North, particularly with the Sayano-Altai region.

\section{The Scythian-Saka époque and sites in Kazakhstan}

The Scythian-Saka époque of the Early Iron Age takes a special place in the history of not only Kazakhstan, but the entire Eurasian steppe. This was the period of vibrant and distinctive processes that resulted in major changes in the lifestyle of the $1^{\text {st }}$ millennium BC steppe populations. The transition to mobile forms of pastoralism (i.e. to "nomadism") involved subsequent innovations in the social organization, economy, material culture and ideology of the people. These new features of the culture and lifestyle of the societies had a great effect on their burial structures and material assemblages, such as enormous kurgans, places of worship, rich artefacts made of bronze, iron, gold and other precious metals and stones. In the 1960s, the term of "Saka cultural community" was introduced (Kadyrbaev 1966) to define the eastern area of the steppe Scythian cultures.

During the past half-century, a number of striking archaeological discoveries have been made in the Kazakhstan steppes, which allowed a more detailed assessment of the development of Saka cultures in the Eurasian steppe. The most significant discoveries include the sites of Besshatyr, Issyk and Zhalauly in the South-East Kazakhstan (Akishev 1978; Akishev and Kushaev 1963; Tasmaganbetov 2003; Samashev et al. 2005), Tagisken and Uigarak in the East Aral Sea Region (Vishnevskaya 1973 and 1992), the sites of the Mayemerskaya culture, as well as impressive archaeological complexes of Berel and Shilikty in Eastern Kazakhstan (Samashev 2011; Toleubaev 2011) and Taldy 2 in Central Kazakhstan (Beisenov 2013). 
The new findings became a powerful factor for the intensification of Scythian-Saka research, forming the basis of the concept of "steppe civilization" of the ancient riders of the Eurasian plains (Martynov 2008). According to this concept, the major achievements of the steppe society were based on highly developed stock-rearing management, rather than crop farming. The former fully took into account environmental factors through the regulation of pastures and water sources, as well as emphasised the role of exchange practices, to the extent of assigning values through warfare.

\section{Tasmola Culture}

Defined in the 1960s, the Tasmola archaeological culture is characterised by strongly marked steppe nomadic appearance, kurgan burials, numerous pieces of weaponry, horse harness and household items (Fig. 1 and 2). Presently, this culture is regarded as a large historical-ethnographic community which included the regions of Central (Beisenov 2011) and Northern Kazakhstan (Habdulina 1994), and southern Trans-Urals (Tairov 2007).

Most Tasmola mounds are large, more than $15-20 \mathrm{~m}$ in diameter and more than $1.5-2 \mathrm{~m}$ high. The smallest mounds are kurgan 3 of the Taisogan graveyard $(0.4 \mathrm{~m}$ high, $8 \mathrm{~m}$ in diameter) and kurgan 11 of the " 37 warriors" cemetery ( $0.4 \mathrm{~m}$ high, $10 \mathrm{~m}$ in diameter). The largest is kurgan 2 of the Nurken-2 graveyard (6 m high, ca. $60 \mathrm{~m}$ in diameter). Limestone, abundant in the tops of hills in the area, was extensively used in the construction of the kurgans, including mounds themselves, tops and around burial pits. Mounds located on the river banks contain clay which obviously replaced stone which is difficult for extraction and transportation. Kurgans always contain single grave, dug in the ground, and in most cases a passage (dromos) orientated to the east or south-east, ranging from $1.5 \mathrm{~m}$ ("37 warriors", kurgan 11) to 15 $m$ in length (Nurken 2, kurgan 2). The deceased are usually orientated towards NW or W.

The early investigations of the Tasmola sites in 1950s and 1960s were mostly focused on kurgans located along the Shiderty River (SW Pavlodar Oblast). On the basis of particular characteristics of burials and grave goods assemblages, it was initially divided into two chronological stages, archaeologically dating to the $7^{\text {th }}-6^{\text {th }}$ and $5^{\text {th }}-3^{\text {rd }} c$. BC respectively (Kadyrbaev 1966). To date, more than 200 kurgans have been investigated. The most important directions of modern research include the investigation of the elite Tasmola burial mounds and investigation of settlements (Beisenov 2002, 2012, 2013; Beisenov and Lohman 2009; Beisenov and Merz 2010; Habdulina 2003).

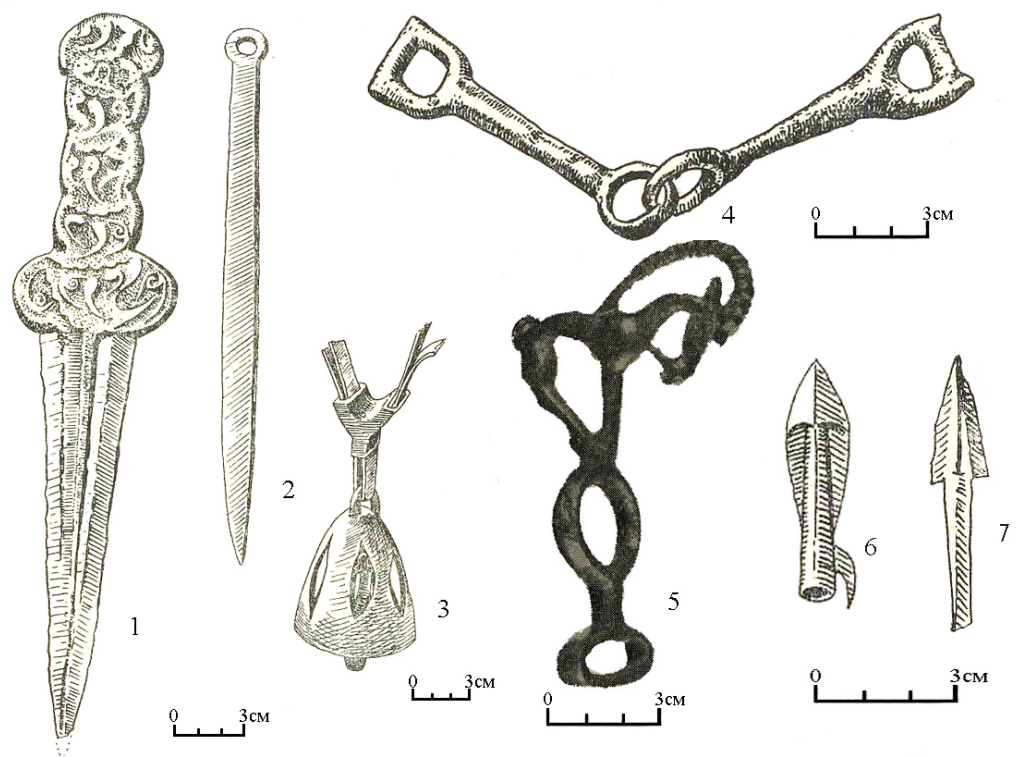

Fig. 1. Bronze artefacts of the Tasmola Culture, SW Pavlodar Oblast (excavations by M.K. Kadyrbaev, 1959-1962, Kadyrbaev 1966): 1, 2, 7 - dagger, knife and arrowhead (Nurmanbet 4, kurgan 1); 3, 4, 5 - bell, bridle bit and figurine of a mountain goat (Tasmola 5, kurgan 2); 6 arrowhead (Karamurun 1, kurgan 5\%). 


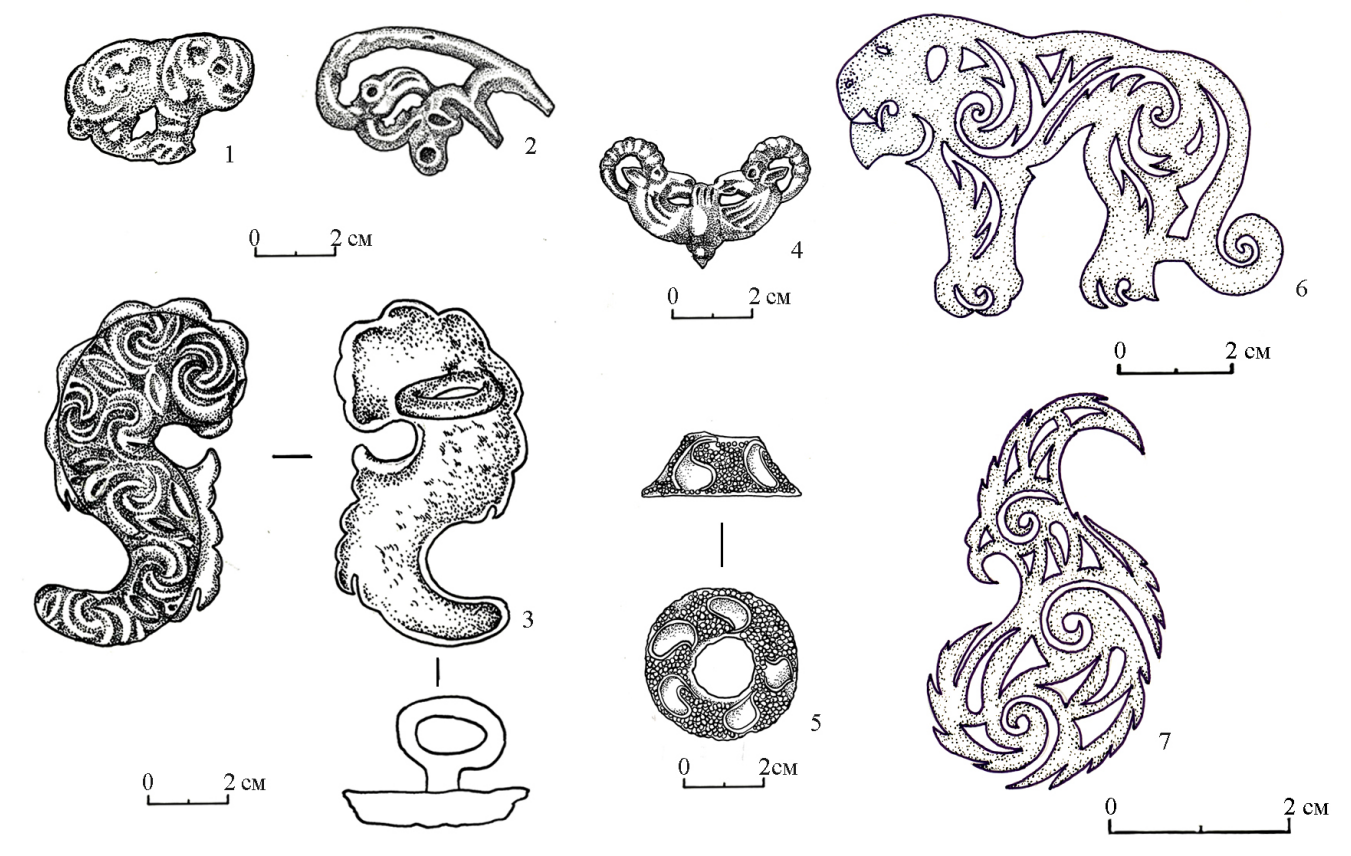

Fig. 2. Golden ornaments of the Saka aristocracy ceremonial costumes from the elite Tasmola kurgans, Karaganda region (excavations by A.Z. Beisenov, 2010-2011): 1, 3, 5- Taldy-2, kurgan 5; 2, 4-Taldy-2, kurgan 2; 6 -Karashoky, kurgan 1; 7 -Sherubai, kurgan 1.

\section{Korgantas Period}

From $4^{\text {th }}$ c. BC, a new type of burial appear in Central Kazakhstan, different from those of the Tasmola Culture. Typically, the burials represent small, round or oval, roughly built mounds from 6-7 m to $10-15 \mathrm{~m}$ in diameter, which is indicative of a change in funeral rites of the people. A chaotic assemblage of stones is often found on the ground above a grave. Enclosure, characteristic for the Tasmola burial mounds especially of the early phase of the Culture, is missing for the Korgantas sites. Typically, the mounds contain a single burial; the deceased are orientated towards NE or E. No passages (dromoi) have been discovered in Korgantas burials. The above features allowed to attribute the burials to a distinctive cultural unit - Korgantas period, defined in 1995 (Beisenov 1995). These sites are characterised by a number of features similar to those of the early Hun burials, such as sacrificial headplaces holding heads of domestic animals (Beisenov 1995, 1997).

To date, a number (less than 40) Korgantas kurgans have been investigated, most of them have been plundered (in some cases - several times), apparently in ancient times; as such, many issues regarding the interpretation of the discoveries remain unaddressed. Archaeologically, this period was dated to the $3^{\text {rd }}-1^{\text {st }}$ c. BC, however, some features (e.g. bone arrowheads) suggest $4^{\text {th }} \mathrm{c}$. BC as the start date of the period (Beisenov 1995, 1997). Specific features of burial structures and artefacts (Fig. 3) suggest that the Korgantas are related to the sites of eastern regions of Central Asia, and that the population might have migrated from Ordos Region of North China (Tairov 2006; Shulga 2011). 

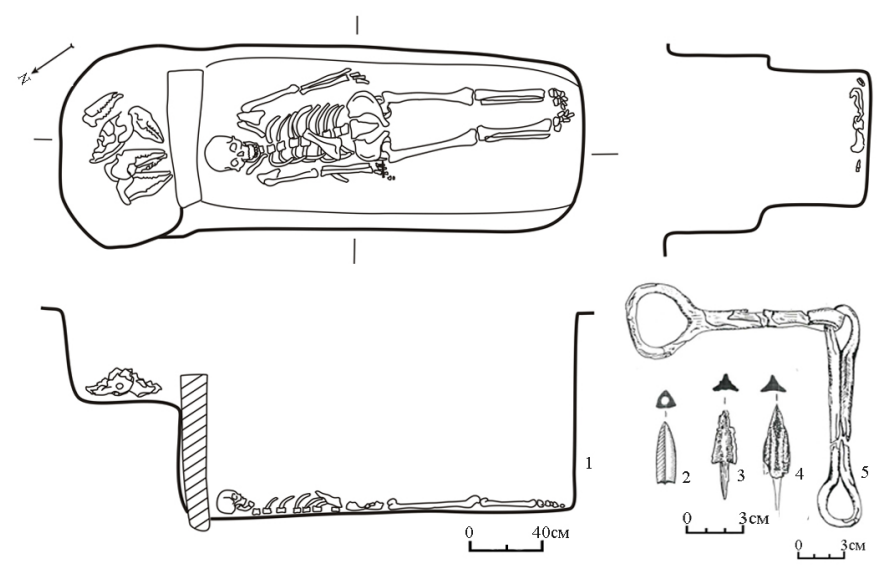

Fig. 3. Burials and artefacts (arrowheads and bridle bits) of the Korgantas period, Birlik cemetery, SW Pavlodar Oblast (excavations by A.Z. Beisenov, 1990): 1 - plan and cross-section of the kurgan 2 burial pit; 2, 3, 4- bone and iron arrowheads and bridle bits, kurgan 19.

\section{Aims of the study}

Since the early stages of the research into the Early Iron Age of Eastern Eurasia, the problems of chronology and periodization have appeared the most topical and included the issues of development of the cultures themselves, as well as their contacts with neighbours. At the moment, the research into the Saka cultures of Kazakhstan is strongly limited by the lack of reliable radiocarbon datasets. In particular, it is virtually impossible to inter-correlate the chronologies of elite Saka kurgans. The routine employment of biochemical methods, including radiocarbon dating, is one of the crucial factors of the modern research into the Early Iron Age cultures of Kazakhstan.

The main aim of this study is to present the radiocarbon chronology of the Tasmola Culture and the Korgantas period, and in particular, to address the issue of the end-date of the second phase of the Tasmola Culture (i.e. the end-date of the Culture itself). The original archaeological attribution of the second phase of the Culture to the $5^{\text {th }}-3^{\text {rd }} \mathrm{c}$. BC (Kadyrbaev 1966) was based on the small number of burials excavated in the 1950es and 1960es, and nowadays this has been challenged. The recently defined Korgantas period, archaeologically dated to $4^{\text {th }} / 3^{\text {rd }}-1^{\text {st }} \mathrm{c}$. BC, chronologically corresponds with the second phase of the Tasmola Culture, which raises a question of the end-date of the latter. The new radiocarbon dating program has a potential of refinement of the end-date of the Tasmola Culture, which, based on archaeological evidence, has been earlier proposed as (possibly start of the) $5^{\text {th }} \mathrm{c}$. BC (Beisenov 1995, 1997). In the broader context, the new ${ }^{14} \mathrm{C}$ dates are of a great importance not only for a regional archaeology, but also for wider research in chronology as a comparative material, as well as serving as a timeframe for DNA research which recently has largely expanded to the Bronze Age of Eurasian Steppe (Haak et al. 2015; Allentoft et al. 2015).

\section{Materials and Methods}

The analysed sites (Fig. 4) were excavated in 2000-2013; they are located in the Kazakh uplands between the south-western part of Pavlodar and eastern part of the Karaganda regions, characterized by vast steppes with high rocky hills. The kurgans are grouped in small cemeteries, located on plains with small rivers or streams, which usually dry up during summers. Particularly large kurgans are located in approximately equal distances of few tens of kilometres, which suggests that they might have been used to mark the location of related families with their lands. 


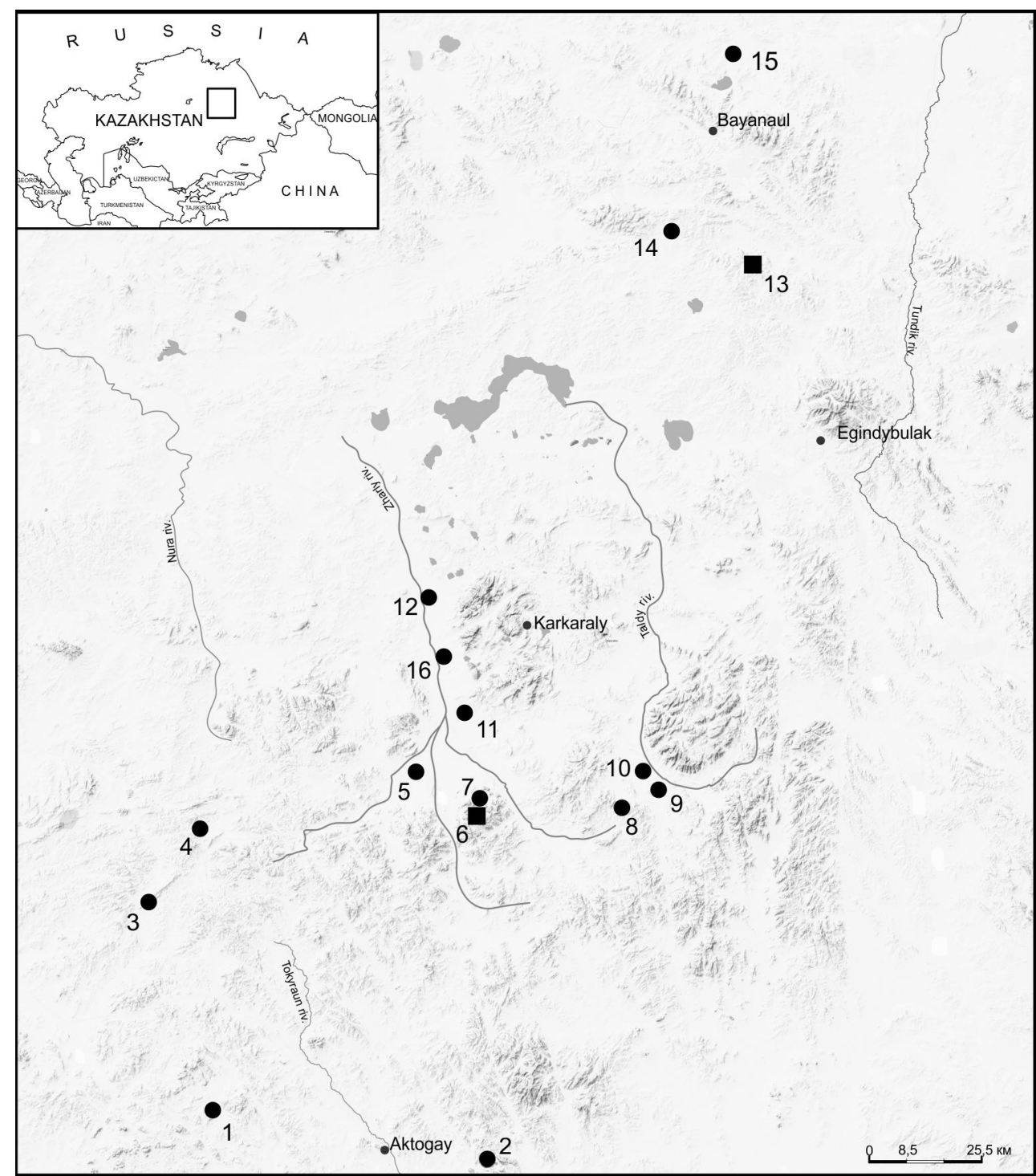

Fig. 4. Location map of the newly discovered Early Iron Age sites of Central Kazakhstan, mentioned in the paper. Circles indicate cemeteries and squares mark settlements. Sites 1-14 belong to the Tasmola Culture, 15 and 16 - to the Korgantas Period). 1. "37 warriors"; 2. Begazy, Kyzyl; 3.

Karashoky; 4. Akbeit 1; 5. Nurken 2; 6. Sarybuirat; 7. Bakybulak; 8. Koitas; 9. Taisoigan; 10. Taldy 2; 11. Nazar 2; 12. Kosoba; 13. Tagibaybulak; 14. Kyzylshilik; 15. Birlik; 16. Bidaik.

In total, 22 adult humans and two animals from 16 sites have been sampled.

Two laboratories have been used to analyse the samples. Two dates were obtained from Beta Analytic (Miami, Florida, USA; the details of pretreatment protocol for these samples are not available). The majority of the AMS ${ }^{14} \mathrm{C}$ dates $(\mathrm{n}=22)$ were obtained from bone collagen samples prepared and analysed in the ${ }^{14} \mathrm{CHRONO}$ Centre for Climate, the Environment and Chronology (Queen's University Belfast) using NEC compact 0.5 MV AMS. Sample bone surfaces were cleaned. Preparation of collagen was based on an ultrafiltration method (Brown et al. 1988; Bronk Ramsey et al. 2004) and included bone demineralization $(2 \% \mathrm{HCl})$, gelatinization (at $58^{\circ} \mathrm{C}$ for 16 hours), filtration, ultrafiltration (using Vivaspin $15 \mathrm{~S}$ ultrafilters with MWCO $30 \mathrm{kDa} ; 3000-3500 \mathrm{rev} / \mathrm{min}$ for 30 minutes), and freeze-drying. The dried collagen was stored in a desiccator. Prepared collagen samples were sealed under vacuum in quartz tubes with an excess of $\mathrm{CuO}$ and combusted at $850^{\circ} \mathrm{C}$. The $\mathrm{CO}_{2}$ was converted to graphite on an iron catalyst using a zinc reduction method (Slota et al. 1987). The graphite was then pressed to produce a "target" and the ${ }^{14} \mathrm{C} /{ }^{12} \mathrm{C}$ and ${ }^{13} \mathrm{C} /{ }^{12} \mathrm{C}$ ratios were measured by AMS. The sample ${ }^{14} \mathrm{C} /{ }^{12} \mathrm{C}$ ratio was background corrected and normalised to the HOXII standard (SRM 4990C; National Institute of Standards and Technology). The ${ }^{14} \mathrm{C}$ age and one standard deviation were calculated using the Libby half-life (5568 years) following the conventions of Stuiver and Polach (1977). The radiocarbon ages were then corrected for isotopic fractionation using the AMS-measured $\delta^{13} \mathrm{C}$, which includes natural and machine 
fractionation (and therefore is not included in the text), and calibrated using Calib 7.0 programme (Stuiver et al. 2013) and IntCal13 calibration curve (Reimer et al. 2013).

\section{Results and Discussion}

For samples analysed in the ${ }^{14} \mathrm{CHRONO}$ Centre, the bone collagen content varied between $3.6 \%$ and $23.1 \%$, which indicates very good collagen preservation (van Klinken 1999; Table 1). The C: $\mathrm{N}_{\text {atomic }}$ ratio was within the accepted range 2.9-3.6, also characterizing a well-preserved collagen (DeNiro 1985).

Table 1. AMS ${ }^{14} \mathrm{C}$ dates, $\mathrm{C}: \mathrm{N}_{\text {atomic }}$ and collagen yield of the samples from the Early Iron Age sites of Central Kazakhstan

Two dates have been published previously in (*) Beisenov 2014a and (**) Beisenov 2014b

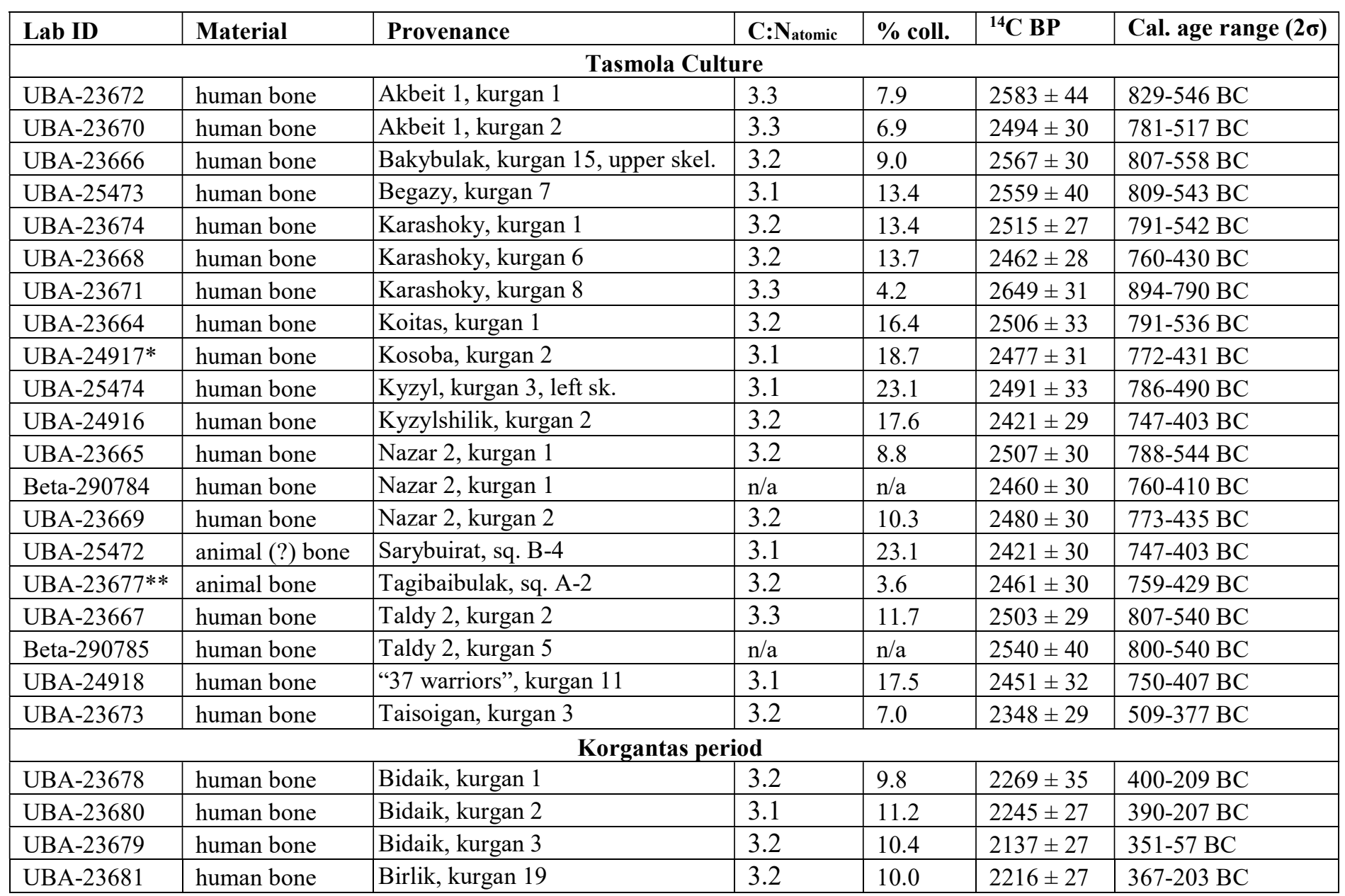




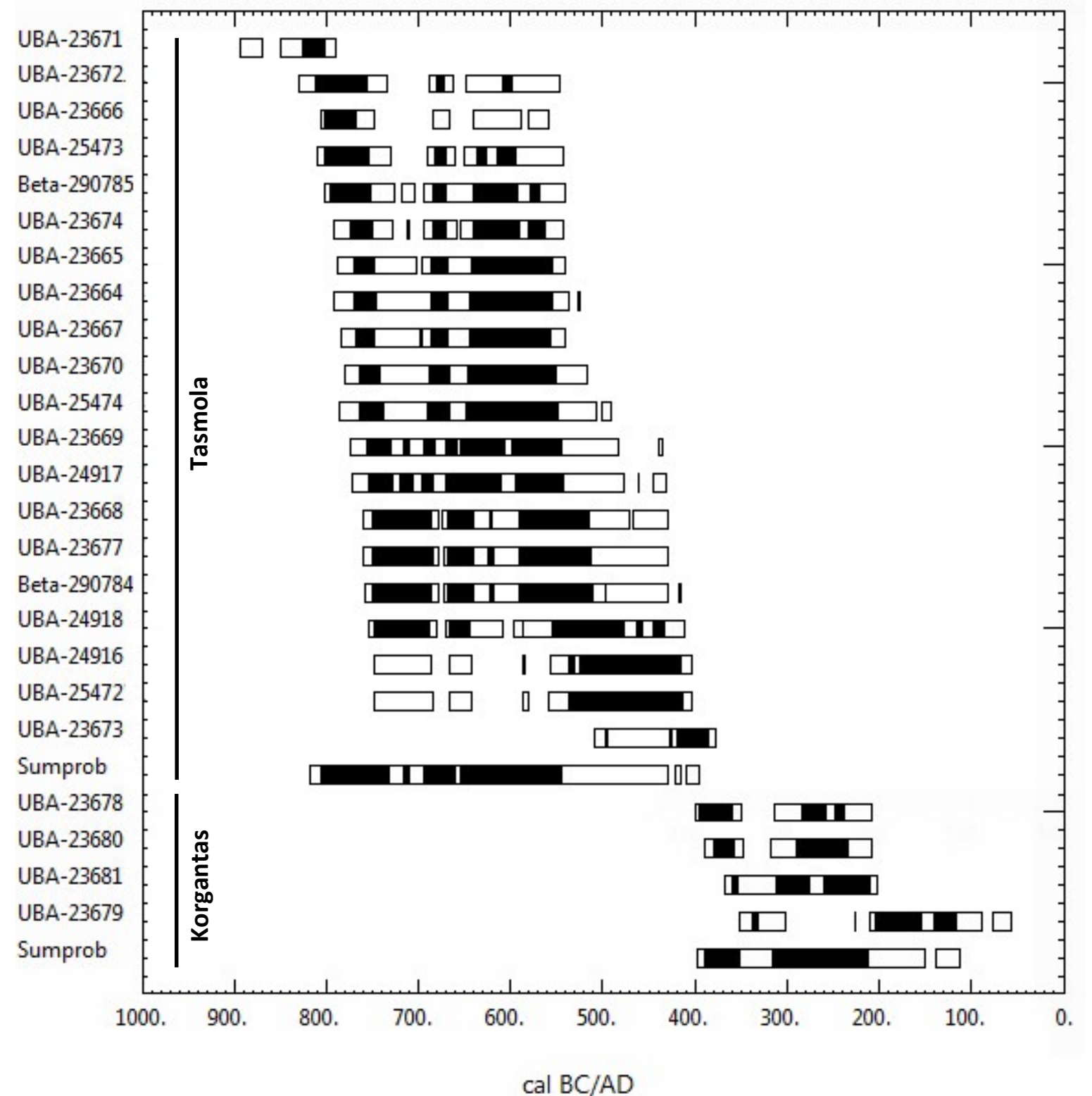

Fig. 5. Calibrated age ranges and summed probabilities $(1$ and $2 \sigma)$ of the Tasmola and Korgantas samples analysed.

Table 1 and Fig. 5 present the results of the ${ }^{14} \mathrm{C}$ measurements for the Tasmola $(n=20)$ and Korgantas $(\mathrm{n}=4)$ samples, as well as summed probabilities for the two periods. In general, the dates for both periods cluster together very well. Summed probabilities for the periods appear as 818-396 cal BC $(2 \sigma)$ for the Tasmola Culture and 397-113 cal BC $(2 \sigma)$ for the Korgantas period. For the Tasmola Culture, the earliest date clearly belongs to kurgan 8 of the Karashoky cemetery (UBA-23671; 894-790 cal BC). The latest date belongs to kurgan 3 of the Taisoigan cemetery (UBA-23673; 509-377 cal BC). Archaeologically, kurgans of the Karashoky cemetery have quite an archaic appearance, including architecture and burial features, same as burials of the Bakybulak and Akbeit 1 cemeteries, the majority of which also have earlier ${ }^{14} \mathrm{C}$ dates. For the same reason (architectural simplicity and roughness, smaller size of burials) the site of Taisogan can archaeologically be attributed to the late phase (decline) of the culture. At the moment, archaeologically it is difficult to develop the internal chronology for the Korgantas sites, as most of the burials have very simple constructive features.

The novel radiocarbon dates of the Early Iron Age Saka sites of Central Kazakhstan, presented here, make it possible to review the most topical issues in the chronology of cultural transitions for the region, primarily, the chronology (start and end dates) of the Tasmola Culture. 
The initial chronological framework for the Tasmola Culture proposed by Kadyrbaev (1966; the two stages of the Culture were dated to the $7^{\text {th }}-6^{\text {th }}$ and $5^{\text {th }}-3^{\text {rd }} c$. BC), was largely based on the widely supported traditional stadial approach to the chronology of Scythian-Saka cultures of steppe Eurasia developed in the first half of the $20^{\text {th }} \mathrm{c}$. (see Klejn 2012). Following this approach, the "Scythian epoch" was dated to the $7^{\text {th }}-3^{\text {rd }} \mathrm{c}$. BC, based on the archaeological dates of the latest Bronze Age sites on one side, and the reign of Modu Chanyu emperor (Xiongnu Empire) and beginning of the Hunno-Sarmatian epoch on the other.

However, since the 1970s, the archaeological meaning of the term of "Scythian époque", as well as the chronology of a number of cultures, have been reconsidered for many regions of the eastern Eurasian Steppe, including Kazakhstan. This was greatly triggered by the research in the Sayan-Altai Region of Southern Siberia and discovery of the Early Scythian burial mound of Arzhan 1 dated to the end of the $9^{\text {th }}$ $-8^{\text {th }}$ c. BC, which is essentially earlier than the "traditional" date for the beginning of the Scythian époque (Gryaznov 1980). The subsequent sensational discovery of the Arzhan 2 kurgan dated to middle to end of the $7^{\text {th }} \mathrm{c}$. BC further challenged the traditional perception of the Early Scythian chronology, which was now considered as starting in the $8^{\text {th }}-7^{\text {th }}$ c. BC (Chugunov 2006; Čugunov et al. 2010).

At the same time, since the 1990s, the problem of the discrepancy of the Tasmola archaeological chronology with that of neighbouring cultures became evident, partly being the result of the insufficient research into the sites. By 2010, a number of newly discovered (and discussed in this paper) Tasmola burial mounds appeared archaeologically younger than those excavated in 1960s by M.K. Kadyrbaev. Their younger date is suggested by the archaic constructive features and particular artefacts; a number of kurgans contained passages (dromoi). The dimensions of newly discovered mounds was rather large - up to 30-50 $\mathrm{m}$ in diameter, 3-5 $\mathrm{m}$ in height, while the kurgans discovered earlier had small mounds up to 15$25 \mathrm{~m}$ in diameter and 0.5-1.5 $\mathrm{m}$ in height. Clearly, these earlier kurgans exceeded the traditional archaeological date of the beginning of Tasmola Culture (i.e. $7^{\text {th }}$ c. BC).

In this context, the ${ }^{14} \mathrm{C}$ dates obtained during the current study, confirm the earlier start-date of the Early Scythian period in Central Kazakhstan. The earliest ${ }^{14} \mathrm{C}$ dates for the Tasmola Culture belong to the $8^{\text {th }} \mathrm{c}$. BC, which makes it approximately one century older compared to the traditional archaeological start-date of $7^{\text {th }} \mathrm{c}$ BC. The results also correspond with data for the beginning of the Early Scythian period in the end of the $9^{\text {th }}-8^{\text {th }} \mathrm{c}$. BC in the Sayan-Altai region (Tishkin 2007), where cultural connections with Central Kazakhstan have been previously observed (Kyzlasov 1977).

The later kurgans of the Tasmola Culture change their appearance - they become smaller and do not contain golden ornaments. Archaeologically, the most representative Tasmola kurgans containing characteristic pieces of horse harness, weaponry and ornaments, disappear by the $5^{\text {th }}-4^{\text {th }} \mathrm{c}$. BC, apparently without an external influence. Obtained ${ }^{14} \mathrm{C}$ dates also suggest the end-date of the Culture as $5^{\text {th }} \mathrm{c}$. $\mathrm{BC}$, thus confirming the archaeological observations and making the end-date of the Culture ca. two centuries older compare to the traditional end-date $\left(3^{\text {rd }} \mathrm{c} . \mathrm{BC}\right)$.

Archaeologically, it appears that a new period starts in Central Kazakhstan in the $4^{\text {th }} \mathrm{c}$. BC, which is confirmed with the new ${ }^{14} \mathrm{C}$ dates. The obtained results suggest $4{ }^{\text {th }}-2^{\text {nd }} \mathrm{c}$. $\mathrm{BC}$ as the most probable date of the Korgantas period, which also indirectly confirms the general end of the Tasmola Culture in the $5^{\text {th }} \mathrm{c}$. $\mathrm{BC}$ (although one can accept the possibility of later dates for particular isolated burials).

It is possible to suggest that a number of late Tasmola burials dating to the $4^{\text {th }} \mathrm{c}$. $\mathrm{BC}$ might be found in the future, possibly in the outskirts of the main areal of the Culture. As such, the next step of our research will include the detailed study of the chronology of the second phase of the Tasmola Culture.

\section{Conclusions}

The presented first radiocarbon database for the Early Iron Age of Central Kazakhstan is an essential step for further archaeological research in the area. The new ${ }^{14} \mathrm{C}$ dates suggest the beginning of the $9^{\text {th }}$ to end of the $4^{\text {th }} \mathrm{c}$. BC as timing of the Tasmola Culture and $4^{\text {th }}$ to beginning of the $2^{\text {nd }} \mathrm{c}$. $\mathrm{BC}$ as timing of the Korgantas period. Thus, the start and end dates of both periods are apparently one to two centuries older than defined originally which corresponds with the latest archaeological data for the region however is somewhat in contrary to the traditional perception of the chronology of Scythian period in Central Kazakhstan. The new dates suggest the beginning of the Early Scythian period in the region in at least the $8^{\text {th }}$ or late $9^{\text {th }} \mathrm{c}$. BC rather than $7^{\text {th }} \mathrm{c}$. BC according to the traditional approach. Further research into the 
chronology of the region will include the investigation of the possible effect of freshwater reservoir on the

${ }^{14} \mathrm{C}$ dates of particular types of samples, including human bone.

\section{References}

Akishev KA. 1978. Kurgan Issyk. Iskusstvo sakov Kazahstana [The Issyk Kurgan. The Saka art of Kazakhstan]. Moscow. 130 p. In Russian.

Akishev KA, Kushaev AV. 1963. Drevnyaya kul'tura sakov i usunei doliny r. Ili [The ancient culture of Saks and Usuni of the Ilya River Valley]. Alma-Ata. 298 p. In Russian.

Alekseev AY, Bokovenko NA, Boltrik Y, Chugunov KA, Cook G, Dergachev VA, Kovalyukh N, Possnert G, Plicht Jvd, Scott EM, Sementsov A, Skripkin V, Vasiliev S, Zaitseva G. 2001. A Chronology of the Scythian Antiquities of Eurasia Based on New Archaeological and 14C Data. Radiocarbon 43:1085-107.

Allentoft ME, Sikora M, Sjögren KG, Rasmussen S, Rasmussen M, Stenderup J, Damgaard PB, Schroeder H, Ahlström T, Vinner L, et al. Population genomics of Bronze Age Eurasia. Nature 522:167172.

Beisenov AZ. 1995. K voprosu o vydelenii pamyatnikov korgantasskogo tipa v Vostochnoi Saryarke (vtoraya polovina - konec I tysyacheletiya do n.e.) [To the question of definition of the Korgantas sites in Eastern Saryarka ( $2^{\text {nd }}$ half to the end of the 1st mil. BC)]. In: Tolubaev AT (ed). Etnokulturnye processy na territorii Kazahstana. Almaty. p. 55-61. In Russian.

Beisenov AZ. 1997. Pogrebal'nye pamyatniki i kul'tovo-ritual'nye sooruzheniya drevnih nomadov Central'nogo Kazahstana (7-1 vv. do n.e.) [Funerary sites and cult-ritual structures of ancient nomads of Central Kazakhstan $\left(7^{\text {th }}-1^{s t}\right.$ c. BC)]. Cand. Sc. thesis abstract. Institute of History and Archaeology. Almaty. 17 p. In Russian.

Beisenov AZ. 2002. To the question of identification and investigation of the Early Iron Age settlements of Central Kazakhstan. Istorichna Nauka: Problemi rozvitku. Materials of the international conference. Lugansk. p. 9-12. In Russian.

Beisenov AZ. 2011. Saryarka: kolybel' stepnoi civilizacii [Saryarka: the cradle of the steppe civilization]. Almaty. 32 p. In Russian.

Beisenov AZ. 2012. Poseleniya rannego zheleznogo veka Central'nogo Kazahstana: k probleme genezisa [Early Iron Age settlements of Central Kazakhstan: to the problem of their genesis]. In: Tolubaev AT (ed). Polevye materialy $i$ issledovaniya kafedry arheologii, etnologii i muzeologii KazNU im. Al-Farabi. V. 2. Materialy i issledovaniya po kulturogeneticheskim processam na territorii drevnego $i$ srednevekovogo Kazahstana. Almaty. p. 27-43. In Russian.

Beisenov A. 2013. Die nekropole Taldy-2 in beziehung zu den kulturen der fruhsakishen zeit osteurasiens. In: H. Partcinger (ed.). Unbekanntes Kasachstan. Archaolgie im Herzen Asiens. II. Bochum. p. 595-608.

Beisenov AZ. 2014a. Issledovaniye kurgana sakskogo vremeni s kamennym izvayaniem na mogilnike kosoba (Centralniy Kazakhstan) [Study of the Saka burial mound with a stone statue in the Kosoba cemetery (Central Kazakhstan)]. In: Tishkin AA (ed) Drevniye i srednevekovye kamenniye izvayaniya Centralnoj Azii. Barnaul: Altai State University Press. p. 7-16. In Russian.

Beisenov AZ. 2014b. Settlement of Tagybajbulak in Central Kazakhstan. Izvestiya Altaiskogo Gosudarstvennogo Universita 4-1(84):35-41. In Russian.

Beisenov AZ, Lohman VG. 2009. Drevnie poseleniya Central'nogo Kazahstana [Ancient settlements of Central Kazakhstan]. Almaty. 264 p. In Russian.

Beisenov AZ, Mertz VK. 2010. K izucheniyu pamyatnikov raiona $\mathrm{r}$. Shiderty [To the study of sites in the area of Shiderty River]. Proceedings of the National Academy of Sciences of the Republic of Kazakhstan, Social Science Series 1:40-45. In Russian.

Bronk Ramsey C, Higham T, Bowles A, Hedges R. 2004. Improvements to the Pretreatment of Bone at Oxford. Radiocarbon 46:155-63. 
Brown TA, Nelson DE, Vogel JS, Southon JR. 1988. Improved collagen extraction by modified Longin method. Radiocarbon 30:171-7.

Chernykh EN, Kuzminykh SV, Orlovskaya LB. 2004. Ancient metallurgy in northern Asia: from the Urals to the Sayano-Altai. In: Linduff K (ed). Metallurgy in Ancient Eastern Eurasia from the Urals to the Yellow River. Lewiston: Edwin Mellen Press. p. 15-36.

Chugunov K, 2006. Sinhronizaciya kul'tur nachala ranneskifskogo vremeni Central'noi Azii, Yuzhnoi Sibiri i Kazahstana [Synchronization of the Early Scythian cultures of Central Asia, Southern Siberia and Kazakhstan]. In: VI Molodin (resp. ed). Sovremenniye Problemy Arheologii Rossii. Materialy Vserossiyskogo Arheologicheskogo Syezda, 23-28 October 2006. V. 2. Novosibirsk. p. 69-71. In Russian.

Čugunov K, Parzinger H, Nagler A. 2010. Der skythenzeitliche Furstenkurgan Aržan 2 in Tuva. Berlin.

DeNiro MJ. 1985. Postmortem preservation and alteration of in vivo bone collagen isotope ratios in relation to palaeodietary reconstruction. Nature 317:806-9.

Gryaznov MP. 1980. Tsarskii kurgan ranneskifskogo vremeni [Arzhan. The Imperial Barrow of the Early Scythian period]. Leningrad. 59 p. In Russian.

Haak W, Lazaridis I, Patterson N, Rohland N, Mallick S, Llamas B, Brandt G, Nordenfelt S, Harney E, Stewardson K, et al. 2015. Massive migration from the steppe was a source for Indo-European languages in Europe. Nature 522:207-211.

Habdulina MK. 1994. Stepnoe Prishim'e v epohu rannego zheleza [Steppe Ishim River region in the Early Iron Age]. Almaty. 170 p. In Russian.

Habdulina MK. 2003. Poseleniya rannesakskogo vremeni na r. Selety [Early Saka Settlements near the Selety River]. In: Akishev K (ed). Stepnaya civilizaciya Vostochnoi Evrazii. V1. Drevnie epohi. Astana. p. 189-214. In Russian.

Hanks BK, Epimakhov AV, Renfrew AC. 2007. Towards a refined chronology for the Bronze Age of the southern Urals, Russia. Antiquity 81:353-67.

Higham T, Warren R, Belinskij A, Härke H, Wood R. 2010. Radiocarvon Dating, Stable Isotope Analysis, and Diet-Derived Offsets in 14C Ages from the Klin-Yar Site, Russian North Caucasus. Radiocarbon 52(2-3):653-70.

Hollund HI, Higham T, Belinskij A, Korenevskij S. 2010. Investigation of palaeodiet in the North Caucasus (South Russia) Bronze Age using stable isotope analysis and AMS dating of human and animal bones. J. Archaeol. Sci. 37:2971-83.

Kadyrbaev MK. 1966. Pamyatniki tasmolinskoi kul'tury [Sites of the Tasmola Culture]. In: Margulan AKh, Akishev KA, Kadyrbaev MK, Orazbayev AM (eds.). Drevnyaya kultura Centralnogo Kazahstana. Alma-Ata. p. 303-433. In Russian.

Kiryushin YF, Tishkin AA (eds). 2009. Rol Estestvenno-Nauchnyh Metodov v Arheologicheskih Issledovaniyah [The Role of Scientific Methods for the Archaeological Research]. Barnbaul: Altai State University Press. 384 p. In Russian.

Klejn LS. 2012. Soviet Archaeology: Schools, Trends, and History. Oxford University Press. 456 p.

Kyzlasov LR. 1977. Uyukskii kurgan Arzhan i vopros proishozhdeniya sakskoi kul'tury [Uyuk kurgan of Arzhan and the question of the origin of the Saka Culture]. Sovetskaya Arheologiya 2:80-86. In Russian.

Lillie MC. 1998. The Mesolithic-Neolithic transition in Ukraine: new radiocarbon determinations for the cemeteries of the Dnieper Rapids Region. Antiquity 72:184-8.

Lillie M, Budd C, Potekhina I, Hedges R. 2009. The radiocarbon reservoir effect: new evidence from the cemeteries of the middle and lower Dnieper basin, Ukraine. J. Archaeol. Sci. 36:256-64.

Martynov AI. 2008. Problemy izucheniya evraziiskoi stepnoi civilizacii [The problems of the research into the Eurasian steppe civilizations]. In: Samashev Z (ed). Nomady kazahskih stepei: etnosociokulturnye processy i kontakty v Evrazii skifo-sakskoi epohi. Materials of International Conference. Astana. p. 10-19. In Russian. 
Molodin VI, Marchenko ZV, Kuzmin YV, et al. 2012. 14C Chronology of Burial Grounds of the Andronovo Period (Middle Bronze Age) in Baraba Forest Steppe, Western Siberia. Radiocarbon 54(34):737-47.

Reimer PJ, Bard E, Bayliss A, Beck JW, et al. 2013. IntCal13 and Marine13 Radiocarbon Age Calibration Curves 0-50,000 Years cal BP. Radiocarbon 55(4):1869-87.

Samashev Z. 2011. Itogi issledovaniya na Bereli [Results of the research in the Berel region]. In: Beisenov AZ (ed). Svideteli tysyacheletii: Arheologiya Kazahstana za 20 let (1991-2011). Almaty. p. 120-155. In Kazakh.

Samashev Z, Grigoryev F, Zhumabekov G. 2005. Drevnosti Almaty [The Antiquities of Almaty]. Almaty. 184 p. In Russian.

Shishlina NI, Zazovskaya EP, van der Plicht J, et al. 2009. Paleoecology, Subsistence, and 14C Chronology of the Eurasian Caspian Steppe Bronze Age. Radiocarbon 51(2):481-99.

Shishlina N, Zazovskaya E, van der Plicht J, Sevastyanov EV. 2012. Isotopes, Plants, and Reservoir Effects: Case Study from the Caspian Steppe Bronze Age. Radiocarbon 54(3-4):749-60.

Shishlina N, Sevastyanov V, Zazovskaya E, van der Plicht J. 2014. Reservoir Effect of Archaeological Samples from Steppe Bronze Age Cultures in Southern Russia. Radiocarbon 56(2):767-78.

Shulga PI. 2011. O zahoroneniyah korgantasskogo tipa [On the Korgantas type graves]. In: Beisenov AZ (ed). Sakskaya kultura Saryarki v kontekste izucheniya etnosociokulturnyh processov stepnoi Evrazii. Karaganda. p. 117-120. In Russian.

Slota JP, Jull A, Linick T, Toolin L. 1987. Preparation of small samples for ${ }^{14} \mathrm{C}$ accelerator targets by catalytic reduction of CO. Radiocarbon 44:167-80.

Sorokin SS. 1969. Bol'shoi Berel'skii kurgan (polnoe izdanie materialov raskopok 1865 i 1959 gg.) [The Big Berel Mound (Complete Edition of Excavations for the Years of 1865 and 1959)]. Trudy Gosudarstvennogo Ermitazha 10:207-227. In Russian.

Stuiver M, Polach HA. 1977. Discussion: Reporting of 14C Data. Radiocarbon 19:355-63.

Stuiver M, Reimer PJ, Reimer RW. 2013. CALIB 7.0. [WWW program and documentation]. URL: http://radiocarbon.pa.qub.ac.uk/calib/calib.html.

Svyatko SV, Mallory JP, Murphy EM, et al. 2009. New Radiocarbon Dates and a Review of the Chronology of Prehistoric Populations from the Minusinsk Basin, Southern Siberia, Russia. Radiocarbon 51(1):243-73.

Tairov AD. 2007. Kochevniki Uralo-Kazahstanskih stepei v VII-VI vv. do n.e. [Nomads of the UralKazakhstan steppes in the $7^{\text {th }}-6^{\text {th }}$ c. BC]. Chelyabinsk. 274 p. In Russian.

Tairov AD. 2006. Pamyatniki korgantasskogo tipa: vzglyad so storony [Korgantas type sites: an outside perspective]. In: Merz VK (ed). Izuchenie pamyatnikov arheologii Pavlodarskogo Priirtysh'ya 2. Pavlodar. p. 182-199. In Russian.

Tishkin AA. 2007. Sozdanie periodizacionnyh i kul'turno-hronologicheskih shem: istoricheskii opyt $i$ sovremennaya koncepciya izucheniya drevnih i srednevekovyh narodov Altaya [The Development of Periodization and Cultural-Chronological Schemes: Historical Experience and Modern Concept of Studying the Prehistoric and Medieval Populations of Altai]. Barnaul. 356 p. In Russian.

Toleubayev A.T. 2011. Itogi issledovanii pamyatnikov rannego zheleznogo veka Tarbagataya i Zhetysuskogo Alatau [Results of studies into the Early Iron Age of Tarbagatay and Zhetysu Alatau Mountains]. In: Beisenov AZ (ed). Svideteli tysyacheletii: Arheologiya Kazahstana za 20 let (1991-2011). Almaty. p. 156-174. In Russian.

van Klinken GJ. 1999. Bone Collagen Quality Indicators for Palaeodietary and Radiocarbon Measurements. J. Archaeol. Sci. 26(6):687-95.

Vishnevskaya O. 1973. Kul'tura sakskih plemen nizov'ev Syrdar'i v VII-Vvv. do n.e. [Culture of the Saka tribes from the Lower Syr Darya River in the $7^{\text {th }}-5^{\text {th }}$ c. BC]. Moscow. In Russian. 
Vishnevskaya OA. 1992. Tsentralny Kazahstan [The Central Kazakhstan]. In: Moshkova MG (ed). Stepnaya Polosa Aziatskoi Chasti SSSR v Skifo-Sarmatskoe Vremya. Moscow: Nauka Publishers. p. 13040. In Russian. 